Responses of 20 patients to 12 labelled antigens and to five antigens and saline in duplicate tested blind.

\begin{tabular}{|c|c|c|c|c|c|c|c|c|c|c|c|c|c|c|c|c|c|c|c|c|}
\hline & \multicolumn{20}{|c|}{ Case } \\
\hline & 1 & 2 & 3 & 4 & 5 & 6 & 7 & 8 & 9 & 10 & 11 & 12 & 13 & 14 & 15 & 16 & 17 & 18 & 19 & 20 \\
\hline & \multicolumn{20}{|c|}{ Twelve labelled antigens } \\
\hline Milk & , & , & & & & & & & & 、 & । & & , & , & & & & & & \\
\hline Cheese & & i & & 、 & & & & v & & i & & & & & & & & & & \\
\hline Candida & & , & 1 & & 1 & & s & 、 & & & & ' & & & ' & ' & & & ' & \\
\hline Maize & & & , & & & & & & & & , & & & & & ' & & , & & , \\
\hline Yeast & & & & & & & & & & & 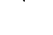 & & & & 1 & 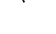 & & 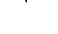 & & 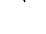 \\
\hline Ethanol & & ' & & & & & & i & & & & & & & & & & & & \\
\hline Beef & & & & ' & & & & , & & & & & & & & ' & & ' & & \\
\hline Lamb & & & & & & 1 & & & & & & & & & & & & & & \\
\hline Pork & & & & & 、 & & & & & & & & & & & & & & & \\
\hline Cod & & & & & & & & & & & & & & & & & & & & \\
\hline Orange & & । & & & & & & & & & & & & & & & & & & \\
\hline Grasses & & , & , & & & & ' & & $\checkmark$ & & & & & & & & ' & & & \\
\hline & & & & & & & & & Five & ind an & ins anc & line & & & & & & & & \\
\hline Cheese & & + & & $(-)$ & & & & + & & $(-)$ & $(+)$ & & & $(+)$ & & $(+)$ & & & $(+)$ & \\
\hline Candida & & + & $(-)$ & & $(-)$ & & $(-)$ & + & & & $(+)$ & $(-)$ & & & + & $(-)$ & & & $(-)$ & \\
\hline Milk & $(-)$ & $(-)$ & $(+)$ & & & & $(+)$ & & & $(-)$ & $(-)$ & & $(-)$ & $(-)$ & & & & & & \\
\hline Yeast & & & & & & $(+)$ & & $(+)$ & & & & & & & $(-)$ & $(+)$ & & $(+)$ & & \\
\hline Yeast & & & $(+)$ & & & & & & & & & & $(+)$ & & $(-)$ & & & & & \\
\hline Maize & & $(+)$ & $(-)$ & & & & & & & & $(-)$ & & & & & $(-)$ & $(+)$ & $(-)$ & & $(-)$ \\
\hline Milk & $(-)$ & + & & $(+)$ & & & & & & $(-)$ & $(-)$ & & $(-)$ & $(-)$ & $(+)$ & & & & & \\
\hline Candida & & $(-)$ & $(-)$ & & $(-)$ & & $(-)$ & $(-)$ & $(+)$ & & & $(-)$ & & & $(-)$ & $(-)$ & & & $(-)$ & \\
\hline Cheese & & $(-)$ & $(+)$ & $(-)$ & $(+)$ & & & $(-)$ & & + & & & & & & & & & & $(+)$ \\
\hline $\begin{array}{l}\text { Saline } \\
\text { Maize }\end{array}$ & & & & $(+)$ & $(+)$ & & & & & & & $(+)$ & & & & $\begin{array}{l}(+) \\
(-)\end{array}$ & & & & $(-)$ \\
\hline $\begin{array}{l}\text { Maize } \\
\text { Saline }\end{array}$ & $(+)$ & $\begin{array}{l}(+) \\
(+)\end{array}$ & $(-)$ & $(+)$ & & & $(+)$ & $(+)$ & & $(+)$ & $(-)$ & & & & & $(-)$ & & + & & $(-)$ \\
\hline
\end{tabular}

$=$ Positive response to labelled antigen

and subsequently modified their diet may well feel better. It is, however, quite a serious step to advise someone to avoid important staple foods, especially if many foods are involved, or if the patient is a young child. ${ }^{4}$ The experimental procedure described above is simple and inexpensive and requires only the cooperation of an impartial observer who will prepare the "blind" antigens. Practitioners who use tests without formal validation may wish to apply similar investigations to their own diagnostic procedures.

1 Lessof MH, chairman. Food intolerance and food aversion. $\mathcal{I} R$ Coll Physicians Lond 1984;18: 83-123.

2 David TJ. Unhelpful recent developments in the diagnosis and treatment of allergy and food intolerance in children. In: Dobbing J, ed. Food intolerance. London: Balliere Tindall, 1987: 185-215.

3 Freed DLJ. Discussion. In: Dobbing J, ed. Food intolerance. London: Balliere Tindall, 1987:215. 4 David TJ. Unorthodox allergy procedures. Arch Dis Child 1987;62:1060-2.

(Accepted 9 February 1988)

Department of Human Nutrition, Medical College of St Bartholomew's Hospital, London EC1M 6BQ

J S GARROW, FRCP, professor of human nutrition

\section{Loss of the Philadelphia chromosome in chronic myeloid leukaemia associated with coeliac disease and splenic atrophy}

Splenic atrophy is common in coeliac disease. ${ }^{1}$ Although elective splenectomy in chronic myeloid leukaemia does not appreciably affect survival, preexisting hyposplenism due to coeliac disease may have influenced the course of leukaemia in the case reported below.

\section{Case report}

In 1972 a 41 year old woman presented with abdominal pain and symptoms of anaemia. Investigations showed deficiencies of iron and folate and hypocalcaemia. Jejunal biopsy showed subtotal villous atrophy; coeliac disease was diagnosed, and she was successfully treated with a gluten free diet. Ten years later a routine blood count showed a haemoglobin concentration of $128 \mathrm{~g} / \mathrm{l}$, platelet count $314 \times$ $10^{9} / 1$, and white cell count $104 \times 10^{9} / 1$ (differential count $69 \%$ neutrophils, $5 \%$ metamyelocytes, $16 \%$ myelocytes, $2 \%$ promyelocytes, $4 \%$ lymphocytes, and $2 \%$ monocytes). Red cell changes included anisocytosis and the presence of target cells and Howell-Jolly bodies. She did not have any symptoms or hepatosplenomegaly. Alkaline phosphatase activity in neutrophils was scored at 4 (control score 126) and the appearance of bone marrow aspirate was consistent with that seen in chronic myeloid leukaemia. The Philadelphia chromosome was identified in all mitotic cells examined.

She was treated with busulphan $4 \mathrm{mg}$ daily, initially, which was reduced to $4 \mathrm{mg}$ weekly over three months as her white cell count and differential returned to normal. One year after busulphan was started the bone marrow karyotype was normal (table) and treatment was stopped. The bone marrow was not hypoplastic at any stage. Hyposplenism was shown by technetium scanning of the liver and spleen; the spleen showed virtually no uptake. Screening for antibodies to parieta cells and antinuclear, mitochondria, and reticulin antibodies yielded negative results. Lymphocyte subsets showed suppression of cells bearing CD4 and CD8 molecules. She remained well with a normal white cell count and no further treatment for a further three years of follow up. Karyotyping during this time showed the Philadelphia chromosome in up to $8 \%$ of cells, and DNA analysis showed no rearrangement of the break cluster region.

Results of haematological and serial karyotype studies of bone marrow of patient with chronic myeloid leukaemia, coeliac disease, and splenic atrophy

\begin{tabular}{|c|c|c|c|c|}
\hline Date & $\underset{(\mathrm{g} / \mathrm{l})}{\text { Haemoglobin }}$ & $\begin{array}{l}\text { White } \\
\text { cell count } \\
\left(\times 10^{9} / 1\right)\end{array}$ & $\begin{array}{l}\text { Platelets } \\
\left(\times 10^{9} / 1\right)\end{array}$ & $\begin{array}{c}\text { No }(\%) \text { of cells } \\
\text { positive for } \\
\text { Philadelphia } \\
\text { chromosome }\end{array}$ \\
\hline 16 August 1983 & 131 & $106 \cdot 0$ & 309 & $25 / 25(100)$ \\
\hline 12 March 1984 & 128 & 6.6 & 429 & $11 / 30(37)$ \\
\hline 5 July 1984 & 122 & $5 \cdot 9$ & 299 & $0 / 36$ \\
\hline 18 January 1985 & 125 & $6 \cdot 5$ & 317 & $1 / 70(1)$ \\
\hline 21 May 1985 & 125 & $6 \cdot 2$ & 385 & $2 / 30(7)$ \\
\hline 2 July 1985 & 131 & $7 \cdot 2$ & 394 & $1 / 43(2)$ \\
\hline 7 November 1985 & 132 & $6 \cdot 6$ & 390 & $2 / 30(7)$ \\
\hline 19 August 1986 & 133 & $7 \cdot 2$ & 335 & $0 / 35$ \\
\hline 13 February 1987 & 132 & 4.9 & 337 & $2 / 50^{\star}(4)$ \\
\hline 26 June 1987 & 129 & 5.9 & 282 & $0 / 36^{\star}$ \\
\hline
\end{tabular}

*Samples tested for rearrangement of break cluster region.

\section{Comment}

A decrease in the proportion of cells positive for the Philadelphia chromosome is uncommon in the absence of myelosuppression. ${ }^{23}$ Golde et al suggested that a further mutation may result in a clone of cells positive for the Philadelphia chromosome that has no growth advantage over normal cells. ${ }^{3}$ Another theory is that a clone of cells negative for the Philadelphia chromosome but otherwise abnormal may persist. ${ }^{4}$ The pathogenesis of leukaemia is a multistep process; we suggest that in our patient pre-existing hyposplenism reduced the growth of the clone positive for the Philadelphia chromosome or increased the clone's sensitivity to treatment with busulphan.

Splenic atrophy occurs in a third of patients with coeliac disease, and impaired splenic function occurs in half. ${ }^{1} \mathrm{~T}$ cell lymphopenia is found after splenectomy as well as in hyposplenism associated with coeliac disease. The cause of hyposplenism in coeliac disease is obscure, although it is strongly associated with the presence of autoantibodies. One theory is that splenic atrophy occurs after prolonged uptake of immune complexes. ${ }^{5}$ 
Although we cannot exclude an unknown interaction between coeliac disease and chronic myeloid leukaemia in our patient, we think that preexisting hyposplenism may have favourably influenced the course of her leukaemia.

We thank Dr L M Wiedman, Chester Beatty Laboratories, London, for the DNA analyses.

1 Bullen AW, Gowland G, Rajah S, Losowsky MS. Hyposplenism, adult coeliac disease and autoimmunity. Gut 1981;22:28-33

2 Brandt L, Mitelman F, Panani A, Lenner HC. Extremely long duration of chronic myeloid leukaemia with Ph negative and Ph positive bone marrow cells. Scand f Haematol 1976;16:321-5. 3 Golde DW, Bersch NI, Sparkes RS. Chromosomal mosaicism associated with prolonged remission in chronic myelogenous leukaemia. Cancer 1975;37:1849-52.

4 Applebaum FR, Najfeld V, Singer JW. Chronic myelogenous leukaemia. Prolonged survival with spontaneous decline in the frequency of $\mathrm{Ph}$ positive cells and subsequent development of mixed $\mathrm{Ph}$ positive and $\mathrm{Ph}$ negative blast crisis. Cancer 1981;51:149-53.

5 Robinson PJ, Bullen AW, Hall R, Brown RC, Baxter P, Losowsky MS. Spleen size and function in adult coeliac disease. Br f Radiol 1980;53:532-7.

(Accepted 12 February 1988)

Department of Haematology, Leicester Royal Infirmary, Leicester LE1 5WW CLAIRE S CHAPMAN, MRCP, MRCPATH, senior registrar

V E MITCHELL, MRCP, MRCPATH, consultant haematologist

Leicester General Hospital, Leciester LE5 4PW

C P T ALEXANDER, FRCP, consultant physician

Department of Human Genetics, Children's Hospital, Sheffield S10 2TH

A M POTTER, PHD, deputy director

Correspondence to: Dr Chapman.

\section{Serological markers of renal itch in patients receiving long term haemodialysis}

Little research has been done on renal itch, which affects up to $86 \%$ of patients who are receiving long term haemodialysis. ${ }^{1}$ Since the first description of uraemic pruritus in 1932 there has been little information about its cause. To try to clarify this we attempted to correlate the degree of itch with several serological variables that are altered during long term haemodialysis.

\section{Patients, methods, and results}

All 68 patients who were receiving long term haemodialysis in the Sunderland renal unit were assessed for suitability for inclusion in the study. Fourteen patients were excluded on the basis of: evidence of an underlying skin disease, judged clinically by one of us (AJC) (six patients); inability either physically or intellectually to complete a visual analogue scale of their itch (five); impaired liver function, measured by serum $\gamma$-glutamyltransferase and aspartate transaminase activities (three). Over one week the remaining 54 patients (10 women), aged 25-79, who had received haemodialysis for 3-123 months, completed visual analogue charts of their itch. Separate charts for day and night were recorded for seven consecutive days, with no reference to previous scores. The score represented the patient's impression of his or her itch over each period. This ranged in increments of five from absent, which scored 0 , to unbearable, which scored 100, making a maximum possible score of 1400 over the week.

During the assessment blood was taken before dialysis to measure the serum concentrations of urea, creatinine, urate, ionised calcium, total calcium, phosphate, alkaline phosphatase, parathyroid hormone, magnesium, and

Degree of itch and distribution of renal osteodystrophy in patients undergoing long term haemodialysis

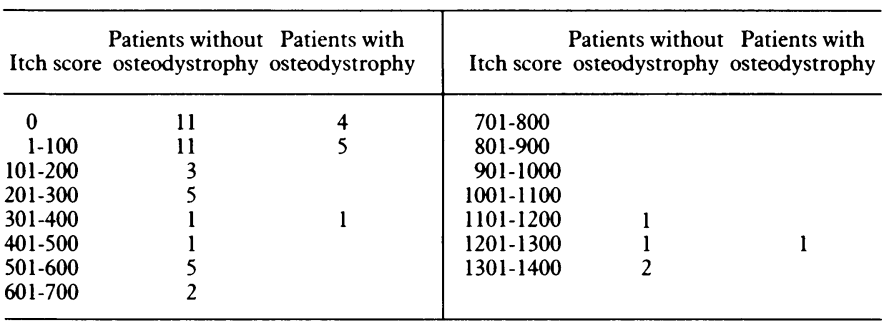

aluminium. The presence of renal osteodystrophy, shown by skeletal survey within the previous three months, was also recorded.

All 54 patients completed the assessment. The table shows the degree of itch and the distribution of renal osteodystrophy in the group. In view of the nonGaussian distribution of the itch scores their relation to the biochemical indices was analysed with the Spearman rank correlation test $\left(\mathbf{r}_{\mathrm{s}}\right)$. Serum magnesium and phosphate concentrations correlated with the degree of itch $\left(r_{\mathrm{s}}=0.38\right.$ and 0.33 , respectively; $p<0.01)$; other indices were unrelated to itch $\left(r_{s}<0.27 ; p>0.05\right)$. A correlation of the products of the divalent ions with itch showed a relation between the magnesium phosphate products and itch $\left(r_{s} 0.47 ; p<0.01\right)$. The results of the Mann-Whitney U test showed no association between itch and the sex of patients or between itch and renal osteodystrophy, which was present in 11 patients.

\section{Comment}

Previous studies have failed to show significant serological markers of uraemic itch. There has, however, been previous inferential evidence that secondary hyperparathyroidism in uraemia is associated with itch. This is based on increased activity of serum alkaline phosphatase ${ }^{1}$ and case reports of dramatic resolution of uraemic pruritus after parathyroidectomy. ${ }^{2} \mathrm{We}$ have failed to show a correlation between renal itch and parathyroid hormone concentration (measured absolutely and by the presence of renal osteodystrophy), confirming the findings of Nielsen et al. ${ }^{3}$ We have shown, however, for the first time to our knowledge, a significant correlation of uraemic pruritus with serum concentrations of phosphate, magnesium, and especially their ionic products before dialysis. Hyperphosphataemia in isolation or artificially induced in renal failure is not, however, associated with itch. ${ }^{2}$ Phosphate may therefore be acting as a marker of the adequacy of the dialysis of an as yet unidentified prurogen.

One case of recalcitrant uraemic pruritus that responded dramatically to lowering the serum magnesium concentration has been described. ${ }^{4}$ The correlation of magnesium concentrations with renal itch in this study provides further evidence of the potential role of this ion. The mechanism can currently only be conjectured. Graf et $a l^{4}$ implicated neurogenic mediation; alternatively, magnesium concentration may influence the release of histamine by mast cells, which are found in increased numbers in the dermis of patients who are receiving haemodialysis. ${ }^{5}$

The effect of altering the serum magnesium concentration in patients who suffer from uraemic itch during long term haemodialysis is now being investigated.

1 Young AW, Sweeney EW, David DS, et al. Dermatological evaluation of pruritus in patients on hemodialysis. NY State f Med 1973;173:2670-4.

2 Massey SG, Popovtzer MM, Coburn JW, Makoff DL, Maxwell MH, Kleeman CR. Intractable

pruritus as a manifestation of secondary hyperparathyroidism in uremia. Disappearance of pruritus as a manifestation of secondary hyperparathyroidism in uremia.
itching after subtotal parathyroidectomy. $N$ Engl 7 Med 1968;279:697-700.

3 Nielsen T, Hemmeloff Andersen KE, Kristiansen J. Pruritus and xerosis in patients with chronic renal failure. Dan Med Bull 1980;27:269-71.

4 Graf H, Kovarik J, Stummvoll HS, Wolf A. Disappearance of uraemic pruritus after lowering dialysate magnesium concentration. Br Med f 1979;ii:1478-9.

5 Matsumoto M, Ichimaru K, Horie A. Pruritus and mast cell proliferation of the skin in end stage renal failure. Clin Nephrol 1985;23:285-8.

(Accepted 8 February 1988)

Department of Medicine, Royal Infirmary, Sunderland SR2 7JE

ANDREW J CARMICHAEL, MB , MRCP, medical registrar

MARY M MCHUGH, MB, FRCP, consultant nephrologist

ANTHONY M MARTIN, PHD, FRCP, consultant nephrologist

Department of Mathematics and Computer Studies, Sunderland Polytechnic, Sunderland SR2 3SD

MALCOLM FARROW, BSC, PHD, lecturer in statistics

Correspondence to: Dr Andrew J Carmichael, The Skin Hospital, Edgbaston, Birmingham B15 1BR.

\section{Correction}

Transvaginal compared with transvesical ultrasonography for recovery of oocytes for in vitro fertilisation

An authors' error occurred in this short report by Mr David Barlow and others (12 March, p 751). The second and third sentences of the patients, methods, and results section should read: "The number of oocytes fertilised per recovery was significantly higher with transvaginal than transvesical ultrasonography $(p<0.01$, Mann-Whitney $U$ test). The number of embryos transferred was significantly different between the two groups $(p<0 \cdot 01$, Mann-Whitney U test). . ." As a result of the different statistical test used the median number of oocytes per recovery shown in the table is no longer significantly different between the two groups. 